\title{
Toxoplasma gondii in sympatric wild herbivores and carnivores: epidemiology of infection in the Western Alps
}

\author{
Ezio Ferroglio ${ }^{*}$, Fabio Bosio, Anna Trisciuoglio and Stefania Zanet
}

\begin{abstract}
Background: Toxoplasma gondii is an apicomplexan parasite that is able to infect almost all warm blooded animals. In Europe, the domestic cat is the main definitive host. Worldwide, 6 billion people are infected with this parasite. The goal of our research is to evaluate the prevalence of $T$. gondii infection in wild animals from a previously unsampled area in Northern Italy where $0.1 \%$ of women seroconvert during pregnancy each year.

Methods: We sampled and tested skeletal muscle and central nervous system tissue of 355 wild animals by PCR ( $n=121$ roe deer Capreolus capreolus, $n=105$ wild boar Sus scrofa, $n=94$ red fox Vulpes vulpes, $n=22$ alpine chamois Rupicapra rupicapra, $\mathrm{n}=13$ red deer (ervus elaphus).

Results: The overall prevalence of infection with T. gondii was 10.99\% (confidence interval (CI) 95\% 8.14\%-14.67\%). A higher rate of infection was recorded in carnivores and omnivores (red fox 20.21\%, Cl 95\% 13.34\%-29.43\%; wild boar $16.19 \%$, Cl 95\% 10.36\%-24.41\%) compared to ruminants (2.48\%, Cl 95\% 0.85\%-7.04\% in roe deer; 0.00\%, Cl 95\% $0.00 \%-22.81 \%$ in red deer, and $0.00 \%$ alpine chamois (Cl 95\% 0.00\%-14.87\%) confirming the importance of tissue cysts in transmitting infection.
\end{abstract}

Conclusions: The relatively high prevalence of T. gondii DNA in highly consumed game species (wild boar and roe deer) gives valuable insights into T. gondii epidemiology and may contribute to improve prevention and control of foodborne toxoplasmosis in humans.

Keywords: Toxoplasma gondii, PCR, ELISA, Wildlife, Livestock, Italy

\section{Background}

Toxoplasma gondii is an apicomplexan parasite that infects a wide variety of warm-blooded animals with an asexual stage in intermediate hosts and a sexual stage in a definitive host, which may be any species of domestic or wild felids [1]. T. gondii zoonotic infection is present worldwide. The study by Torgerson and Macphearson, [2] reviewed global seroprevalence values in women of childbearing age that are reported to range from $6 \%$ to $80 \%$. In humans infection can be congenital or can be acquired postnatally by ingesting tissue cysts from undercooked meat, or by consuming food/drink contaminated with oocysts $[3,4]$. In the study area (Piedmont Region, Italy) seroprevalence in women of childbearing age is

\footnotetext{
* Correspondence: ezio.ferroglio@unito.it

Dipartimento di Scienze Veterinarie, Università degli Studi di Torino, via L. da Vinci 44 10095, Grugliasco, (TO), Italy
}

(c) 2014 Ferroglio et al.; licensee BioMed Central Ltd. This is an Open Access article distributed under the terms of the Creative Commons Attribution License (http://creativecommons.org/licenses/by/4.0), which permits unrestricted use, distribution, and reproduction in any medium, provided the original work is properly credited. The Creative Commons Public Domain Dedication waiver (http://creativecommons.org/publicdomain/zero/1.0/) applies to the data made available in this article, unless otherwise stated.
$21.5 \%$ [5] and the incidence of infection during pregnancy is $0.1 \%$ [6]. Raw or cured meat products, especially pork, mutton and wild game, are the principal sources of infection [7-10]. Game meat is traditionally consumed in Northern Italy (4 kg/year per capita in hunters families) [11] with an increasing trend linked to the growth of wild ungulate populations [12,13]. In 2011, 1600 chamois, 3460 roe deer, 611 red deer and more than 10,000 wild boar were harvested during hunting season [14]. Considering the abundance of big game species in the study area and the zoonotic burden of toxoplasmosis, we decided to assess T. gondii prevalence within a previously unsampled area in Northern Italy.

\section{Methods}

All tested animals were sampled within the Piedmont Region (Northwestern Italy) from an overall area of $20,000 \mathrm{~km}^{2}$. A 
portion of skeletal muscle was collected from 355 wild ungulates and carnivores hunted or accidentally found dead between October 2009 and December 2012 (ethical approval to the project was given by Dept. Veterinary Sciences, University of Turin). From 213, it was also possible to sample and test a portion of the central nervous system (CNS) of these animals (Table 1). Five wild species were sampled: roe deer Capreolus capreolus $(\mathrm{n}=$ 121), red deer Cervus elaphus $(\mathrm{n}=13)$, alpine chamois Rupicapra rupicapra $(\mathrm{n}=22)$, wild boar Sus scrofa ( $\mathrm{n}=$ 105), and red fox Vulpes vulpes $(\mathrm{n}=94)$ (Table 1). Each sample was individually stored at $-20^{\circ} \mathrm{C}$ until further processing.

a. Molecular detection of T. gondii: sample processing and PCR analysis

Total genomic DNA was extracted from $\approx 25 \mathrm{mg}$ of skeletal muscle and from $\approx 25 \mathrm{mg}$ of CNS homogenate, using the commercial GenElute ${ }^{\odot}$ Mammalian Genome DNA Miniprep (Sigma-Aldrich, St. Louis, MO, USA). Extracted DNA was quantified using NanoDrop 2000 (NanoDrop Technologies, Montchanin, DE, USA). PCR targeted a 200-300 fold repetitive 529 bp DNA fragment using as primers TOX4 (5'CGCTGCAGGGAGGAAGACGAAAGTTG-3') and TOX5 (5'-CGCTGCAGACACAGTGCATCTGGA TT-3') [15]. The PCR reaction mixture $(25 \mu \mathrm{l})$ contained $\approx 100$ ng of DNA template, $2.5 \mu$ l 10X PCR buffer, $5 \mu \mathrm{l}$ of $\mathrm{Q}$ Buffer, $2.5 \mathrm{UI}$ of HotStarTaq DNA Polymerase (Qiagen, Milan, Italy), $0.5 \mu \mathrm{l}$ of dNTPs mix (10 mM of each dNTP, Sigma-Aldrich, St. Louis, MO, USA), and $12.5 \mathrm{pmol}$ of each primer. An initial denaturation step of $15 \mathrm{~min}$ at $95^{\circ} \mathrm{C}$ was followed by 35 repeats of $1 \mathrm{~min}$ at $94^{\circ} \mathrm{C}, 1 \mathrm{~min}$ at $55^{\circ} \mathrm{C}$, and $1 \mathrm{~min}$ at $72^{\circ} \mathrm{C}$, and a final elongation step of $10 \mathrm{~min}$ at $72^{\circ} \mathrm{C}$. PCR amplicons were visualized on a $2 \%$ agarose gel, with a UV transilluminator (GelDoc 1000, Bio-Rad, Hercules, CA). All PCR positive am plicons were purified (Nucleospin Extract II kit, Macherey-Nagel, Düren, Germany) and directly sequenced (Macrogen Europe, The Netherlands) to confirm PCR results. All standard precautions were taken to minimize the risk of cross-contamination (PCR preparation and addition of DNA was carried out in separate laminar-flow cabinets using DNA-free disposable material. Positive and negative controls were processed in parallel to all samples).

\section{b. Statistical analysis}

R software 3.0.1 [16] was used for statistical analysis. Risk factors were assessed separately for each species. We considered the potential risk factors for T. gondii infection as: species, sex, age and the year of sampling. To compare the performance of PCR on skeletal muscle and on CNS we used the Mc Nemar's test for paired data.

\section{Results and discussion}

The overall prevalence of infection recorded in the wild species tested in Northwestern Italy was 10.99\% [39/355] (CI 95\%, 8.14\%-14.67\%). PCR on skeletal muscle ( $\mathrm{p}=$ 9.86\%; CI 95\%, 7.17\% - 13.4\%) resulted significantly more sensible $\left(\mathrm{X}^{2}=11.11, \mathrm{p}<0.005\right)$ in detecting T. gondii DNA than on CNS ( $\mathrm{p}=2.35 \%$; CI 95\%, 1.01\% - 5.38\%). Nevertheless, testing CNS allowed us to detect 4 positive animals that tested negative by PCR on muscle. The highest prevalence was recorded in red fox $(\mathrm{p}=20.21 \%$; CI $95 \%$, $13.34 \%-29.43 \%$ ) followed by wild boar ( $\mathrm{p}=16.19 \%$; CI $95 \%, 10.36 \%-24.41 \%)$ and roe deer $(\mathrm{p}=2.48 \%$; CI $95 \%$, $0.85 \%-7.04 \%)$. None of the red deer ( $p=0 \%$; CI 95\%, $0 \%$ $22.81 \%$ ) or chamois ( $\mathrm{p}=0 \%$; CI $95 \%, 0 \%-14.87 \%)$ tested positive (Table 1). The prevalence of $T$. gondii infection in red fox (Odds Ratio $=3.05 ; \mathrm{X}^{2}=11.13 ; \mathrm{p}<0.001$ ) and in wild boar (Odds Ratio $=2.0 ; \mathrm{X}^{2}=4.13$; $\mathrm{p}<0.05$ ) was significantly higher than in the other tested species but no significant difference existed between the two species (Odds ratio $=1.311 ; \mathrm{X}^{2}=0.54 ; \mathrm{p}>0.1$ ). The relatively high prevalence $(\mathrm{p}=10.99 \%)$ of $T$. gondii recorded in Piedmont evidenced a widespread presence of the parasite in wildlife although relevant discrepancies exist among the tested species. The parasite was absent or was found at very low prevalence in ruminants: red deer and chamois $(0 \%)$, roe

Table 1 PCR results on skeletal muscle and CNS of tested wildlife species

\begin{tabular}{|c|c|c|c|c|c|c|}
\hline \multirow[t]{2}{*}{ Species } & \multicolumn{2}{|c|}{ Skeletal muscle } & \multicolumn{2}{|r|}{ CNS } & \multicolumn{2}{|c|}{ Total } \\
\hline & PCR pos/total & Prevalence [Cl 95\%] & PCR pos/total & Prevalence [Cl 95\%] & Total pos/total & Prevalence [Cl 95\%] \\
\hline Roe deer & $3 / 121$ & $2.48 \%[0.85-7.04]$ & $0 / 72$ & $0 \%[0-5.07]$ & $3 / 121$ & $2.48 \%[0.85-7.04]$ \\
\hline Wild boar & $17 / 105$ & $16.19 \%[10.36-24.41]$ & $0 / 60$ & $0 \%[0-6.02]$ & $17 / 105$ & $16.19 \%[10.36-24.41]$ \\
\hline Red fox & $15 / 94$ & $15.96 \%[9.92-24.67]$ & $5 / 81$ & $6.17 \%[2.67-13.65]$ & $19 / 94$ & $20.21 \%[13.34-29.43]$ \\
\hline Alpine chamois & $0 / 22$ & $0 \%[0-14.87]$ & $0 / 0$ & n.d. & $0 / 22$ & $0 \%[0-14.87]$ \\
\hline Red deer & $0 / 13$ & $0 \%[0-22.81]$ & $0 / 0$ & n.d. & $0 / 13$ & $0 \%[0-22.81]$ \\
\hline Total & $35 / 355$ & $9.86[7.17-13.4]$ & $5 / 213$ & $2.35 \%[1.01-5.38]$ & $39 / 355$ & $10.99 \%[8.14-14.67]$ \\
\hline
\end{tabular}

Skeletal muscle and CNS were tested in parallel by PCR for T. gondii. PCR results obtained on each tissue type are reported separately for each of the tested animal species. 
deer (2.48\%), while higher prevalence of infection was recorded in omnivores (wild boar $\mathrm{p}=16.19 \%$ ) and carnivores (red fox $\mathrm{p}=20.21 \%$ ) respectively. These findings confirm what Smith and Frenkel [1] described for North America, where increasingly higher prevalence of infection was found in herbivores (9\%), omnivores (21\%) and carnivores (52\%). This reflects the higher probability of a carnivore or omnivore to consume tissues infected with $T$. gondii than the probability of a herbivore to ingest $T$. gondii oocysts from the environment. This is especially true in epidemiological contexts where there is only one species acting as definitive host (in the studied area it is the domestic cat) and contributing to oocyst dissemination [1]. Prevalence in red fox ranged from $14 \%$ in Germany [17] to $16.1 \%$ in Central Italy [18], $18.8 \%$ in Belgium [19] and 68\% in Hungary [20]. PCR results on wild boar from France recorded a prevalence of $14.19 \%$ [21], while $5 \%$ of Belgian roe deer and $0 \%$ of red deer were positive by PCR [19]. The absence or low prevalence of infection in alpine chamois and red deer is consistent with previous data $[22,23]$. In the study area the alpine chamois has an altitudinal range between 600 and $2700 \mathrm{~m}$ a.s.l. In the high altitude alpine area occupied by chamois and red deer there are no major urban settlements nor anthropic areas hence domestic cats are uncommon and infection with sporulated oocysts is unlikely to occur. On the contrary roe deer is a ubiquitous and more synanthropic species, which is more likely to encounter oocysts. In Sylvilagus floridanus from the same geographical area, T. gondii was recorded with a prevalence of $2.08 \%$ [24]. S. floridanus is as ubiquitous as roe deer, and feeds exclusively from the ground. For both C. capreolus and S. floridanus tissue cyst consumption can be ruled out, and their similar infection rates (2.48\% and $2.08 \%)$ can be ascribed to consumption of oocysts eliminated by cats into the environment. Both surface water $[25,26]$ as well municipal drinking water [27] can be highly contaminated, and are recognized as among the major sources of infection [25,26]. Future genotyping by PCR-RFLP $[28,29]$ of $T$. gondii isolates will allow a clearer understanding of the role of wildlife in $T$. gondii epidemiology as a recent work by Wendte et al. [30] evidenced that, beside the widespread genotype II, wildlife hosts several recombinant genotypes.

\section{Conclusions}

Economic, social and bioclimatic changes are causing ever-increasing contact among wildlife, humans and domestic animals [31] and the role of wildlife as a source of zoonotic diseases should be specially monitored [32]. Game meat consumption is steadily increasing [12] and the presence of $T$. gondii DNA in skeletal muscles of $16.19 \%$ of wild boar and $2.48 \%$ of roe deer could indicate a possible source of human infection. Wildlife can become a valuable indicator of environmental contamination with $T$. gondii oocysts.

\section{Competing interests}

The authors declare they have no competing interests.

\section{Authors' contributions}

EF coordinated sample collection and testing, FB and AT performed the experiments and analyzed data, SZ drafted the manuscript. All authors read and approved the final version of the manuscript.

\section{Acknowledgements}

This work was partially funded by the Regional Administration ("Convenzione tra la Regione Piemonte e la facoltà di Medicina Veterinaria dell'Università degli Studi di Torino per la razionalizzazione ed integrazione delle attività di raccolta e smaltimento degli animali selvatici morti o oggetto di interventi di contenimento"). The authors would like to acknowledge, Drs. Grande Davide, Maria Grazia Carpignano, and Isabella Nicola for their precious help in sample collection. We also would like to acknowledge two anonymous reviewers whose help greatly improved the quality of the manuscript.

Received: 3 March 2014 Accepted: 14 April 2014

Published: 24 April 2014

\section{References}

1. Smith DD, Frenkel JK: Prevalence of antibodies to Toxoplasma gondii in wild mammals of Missouri and east central Kansas: biologic and ecologic considerations of transmission. J Wildlife Dis 1995, 31(1):15-21.

2. Torgerson PR, Macpherson CNL: The socioeconomic burden of parasitic zoonoses: Global trends. Vet Parasitol 2011, 182(1):79-95.

3. Buxton D: Ovine toxoplasmosis: a Review. J R Soc Med 1990, 83:509-511.

4. Dubey JP, Sundberg JP, Matiuck SW: Toxoplasmosis associated with abortion in goats and sheep in Connecticut. Am J Vet Res 1981, 42(9):1624-1626.

5. De Paschale M, Agrappi C, Clerici P, Mirri P, Manco MT, Cavallari S, Vigano EF: Seroprevalence and incidence of Toxoplasma gondii infection in the Legnano area of Italy. Clin Microbiol Infec 2008, 14(2):186-189.

6. Pezzoli L, Marotta V, Sattanino G, Griglio B: Toxoplasmosis in italian pregnant women: results of a survey on perception of foodborne risks. J Food Protect 2009, 3:456-684.

7. Dubey JP: Toxoplasmosis. J Am Med Assoc 1994, 205:1593-1598.

8. Kapperud G, Jenum PA, Stray Pedersen B, Melby KK, Eskild A, Eng J: Risk factors for Toxoplasma gondii infection in pregnancy - results of a prospective case-control study in Norway. Am J Epidemiol 1996, 144:405-412.

9. Baril L, Ancelle T, Goulet V, Thulliez P, Tirard-Fleury V, Carme B: Risk factors for Toxoplasma infection in pregnancy: a casecontrol study in France. Scand J Infect Dis 1999, 31:305-309.

10. Kijlstra A, Jongert $\mathrm{E}$ : Control of the risk of human toxoplasmosis transmitted by meat. Int J Parasitol 2008, 38:1359-1370.

11. Ramanzin M, Amici A, Casoli C, Esposito L, Lupi P, Marsico G, Mattiello S, Olivieri O, Ponzetta MP, Russo C, Trabalza Marinucci M: Meat from wild ungulates: ensuring quality and hygiene of an increasing resource. Ital J Anim Sci 2010, 9:318-331.

12. Côté SD, Rooney TP, Tremblay JP, Dussault C, Waller DM: Ecological impacts of deer overabundance. Annu Rev Ecol Evol S 2004, 35:113-147.

13. Avagnina A, Nucera D, Grassi MA, Ferroglio E, Dalmasso A, Civera T: The microbiological conditions of carcasses from large game animals in Italy. Meat Sci 2012, 91:266-271.

14. Regione Piemonte, Osservatorio Faunistico Regionale. accessed January 14th, 2014; http://www.regione.piemonte.it/agri/area_tecnico_scientifica/ osserv_faun/.

15. Homan WL, Vercammen M, De Braekeleer J, Verschueren H: Identification of a 200- to 300-fold repetitive 529 bp DNA fragment in Toxoplasma gondii, and its use for diagnostic and quantitative PCR. Int J Parasitol 2000, 30:69-75.

16. R Development Core Team: R: A Language and Environment for Statistical Computing. Vienna, Austria: R Foundation for Statistical Computing; 2008. URL http://www.R-project.org. ISBN 3-900051-07-0.

17. Herrmann DC, Maksimov P, Maksimov A, Sutor A, Schwarz S, Jaschke W, Schliephake A, Denzin N, Conraths FJ, Schare G: Toxoplasma gondii in foxes 
and rodents from the German Federal States of Brandenburg and Saxony-Anhalt: Seroprevalence and genotypes. Vet Parasitol 2012, 185:78-85.

18. Mancianti F, Verin R, Ariti G, Nardoni S, Mugnaini L, Papini R: Preliminary result on prevalence of $T$. gondii in free ranging red foxes in the province of Pisa: a serological and molecular approach. Parassitologia 2010, 52(1-2):280.

19. De Craeye S, Speybroeck N, Ajzenberg D, Darde ML, Collinet F, Tavernier P, Van GS, Dorny P, Dierick K: Toxoplasma gondii and Neospora caninum in wildlife: common parasites in Belgian foxes and Cervidae? Vet Parasitol 2011, 178:64-69

20. Jakubek EB, Farkas R, Pàlfi V, Mattson JG: Prevalence of antibodies against Toxoplasma gondii and Neospora caninum in Hungarian red foxes (Vulpes vulpes). Vet Parasitol 2007, 144:39-44.

21. Richomme C, Aubert D, Gilot-Fromont E, Ajzenberg D, Mercier A, Ducrot C, Ferte H, Delorme D, Villena I: Genetic characterization of Toxoplasma gondii from wild boar (Sus scrofa) in France. Vet Parasitol 2009, 164:296-300.

22. Gaffuri A, Giacometti M, Tranquillo VM, Magnino S, Cordioli P, Lanfranchi P: Serosurvey of roe deer, chamois and domestic sheep in the central Italian alps. J Wildl Dis 2006, 42:685-690.

23. Formenti N, Gaffuri A, Vicari N, Trogu T, Viganò R, Ferrari N, Paterlini F, Lanfranchi P: Molecular Detection of Toxoplasma Gondii from a Naturally Infected Alpine Chamois (Rupicapra r. Rupicapra) from Italian Alps. Bellver de Cerdanya, Spain: II Rupicapra Symposium, Biology, health, monitoring, and management; 2013.

24. Zanet S, Palese V, Trisciuoglio A, Canton Alonso C, Ferroglio E: Encephalitozoon cuniculi, Toxoplasma gondii and Neospora caninum infection in invasive Eastern Cottontail Rabbits Sylvilagus floridanus in Northwestern Italy. Vet Parasitol 2013, 197(3-4):682-684.

25. Vesco G, Buffolano W, La Chiusa S, Mancuso G, Caracappa S, Chianca A, Villari S, Currò V, Liga F, Petersen E: Toxoplasma gondii infections in sheep in Sicily, Southern Italy. Vet Parasitol 2007, 146:3-8.

26. Villari S, Vesco G, Petersen E, Crispo A, Buffolano W: Risk factors for toxoplasmosis in pigs bred in Sicily, Southern Italy. Vet Parasitol 2009, 161(1-2):1-8.

27. Wainwright KE, Miller MA, Barr BC, Gardner IA, Melli AC, Essert T, Packham AE, Truong T, Lagunas-Solar M, Conrad PA: Chemical inactivation of Toxoplasma gondii oocysts in water. J Parasitol 2007, 93(4):925-931.

28. Su C, Evans D, Cole RH, Kissinger JC, Ajioka JW, Sibley LD: Recent expansion of Toxoplasma through enhanced oral transmission. Science 2003, 299:414-416

29. Jiang HH, Huang SY, Zhou DH, Zhang XX, Su C, Deng SZ, Zhu XQ: Genetic characterization of Toxoplasma gondii from pigs from different localities in China by PCR-RFLP. Parasit Vectors 2013, 6:227.

30. Wendte JM, Gibson AK, Grigg ME: Population genetics of Toxoplasma gondii: new perspectives from parasite genotypes in wildlife. Vet Parasitol 2011, 182:96-111.

31. Daszak P, Cunningham AA, Hyatt AD: Anthropogenic environmental change and the emergence of infectious diseases in wildlife. Acta Trop 2001, 78:103-116.

32. Daszak $P$, Andrew A, Hyatt AD, Cunningham AA: Emerging infectious diseases of wildlife- threats to biodiversity and human health. Science 2000, 287(5452):443-449.

\section{doi:10.1186/1756-3305-7-196}

Cite this article as: Ferroglio et al:: Toxoplasma gondii in sympatric wild herbivores and carnivores: epidemiology of infection in the Western Alps. Parasites \& Vectors 2014 7:196

\section{Submit your next manuscript to BioMed Central and take full advantage of:}

- Convenient online submission

- Thorough peer review

- No space constraints or color figure charges

- Immediate publication on acceptance

- Inclusion in PubMed, CAS, Scopus and Google Scholar

- Research which is freely available for redistribution 